\title{
THE EFFECTS OF HOUSEHOLD INCOME VOLATILITY ON DIVORCE
}

\author{
John M. Nunley* \\ Middle Tennessee State University, Murfreesboro, TN
}

\begin{abstract}
This paper extends empirical research on marital instability in two dimensions. First, I examine the effects of household income volatility on divorce. Second, I examine the effects of household income volatility on the divorce behavior of lower- and higherhousehold income individuals. The results indicate that increases in household income volatility raise the probability of divorce for men, regardless of whether the household income shocks are positive or negative. For women, the effect is not consistent across different household income volatility measures; however, the preferred model specification suggests that only negative shocks raise the risk of divorce.
\end{abstract}

Key words: divorce, household income volatility, household income shocks

JEL Categories: J12, J30, D10

* John M. Nunley, Department of Economics and Finance, Middle Tennessee State University, Murfreesboro, TN 37132, phone: 615-869-8918, fax: 615-898-5596, email: jmn2a@mtsu.edu.

* I thank Charles Baum, Tony Eff, Stuart Fowler, Greg Givens, Mark Owens, Alan Seals, Joachim Zietz, and participants at the 2006 Southern Economic Association meetings for their assistance and helpful comments. Any remaining errors are my own.

** Date of draft: September 13, 2007. 


\section{INTRODUCTION}

The theory developed by Becker et al. (1977) contends that "surprises," whether positive or negative, should have a positive effect on the probability of divorce. In Becker et al.'s framework, household income volatility serves as a proxy for surprises or unexpected events. Their model predicts that household income volatility increases the risk of divorce because unexpected changes alter the couples' expected returns from marriage. Negative shocks to household income could lower the returns from marriage below a particular threshold level, which may lead to divorce. Positive shocks could induce a self-reliance effect, which may also increase the risk of divorce. It could also be that positive or negative household income shocks change the values of outside options.

A number of studies examine the effect of earnings shocks on consumption and other economic outcomes. ${ }^{1}$ However, there have been few studies that examine the effects of earnings shocks on divorce. Previous attempts to measure the effects of earnings shocks on divorce have used actual minus predicted earnings (Becker et al. 1977), changes in predicted earnings capacities (Weiss and Willis 1997), job displacement (Charles and Stephens 2004), and relative spousal income volatility (Hess 2004).

This paper provides an alternative proxy for earnings shocks by examining the effect of household income volatility on divorce. The measures of earnings shocks used in this paper differ from previous measures in two distinct ways: spousal incomes are jointly considered and positive and negative household income shocks are separately identified. Because the decision to divorce is a dynamic process, I use panel data from the 1979 cohort of the National Longitudinal Survey of Youth (NLSY79). I construct two

\footnotetext{
${ }^{1}$ For example, see Charles (1999), Cullen and Gruber (2000), Stephens (2001, 2004), and Blundell and Pistaferri (2003).
} 
measures of household income volatility, one of which exploits potentially exogenous variation in the occupations of individuals. The first measure is the coefficient of variation over three-year periods. The second measure decomposes household income into permanent, transitory, and volatility components. The use of the two volatility measures relates to the differing assumptions governing the measures and the potential endogeneity problem associated with the first measure (i.e. coefficient of variation). The decomposition approach uses additional information in the first-stage regression that is shown to have no predictive power in the divorce equations, but has significant predictive power in the first-stage models.

The empirical models also include indicator variables that separately capture the effects of negative household income movements through time, since whether household income volatility stems from positive or negative household income shocks is otherwise not identified. For men, the effects of positive and negative household income volatility are statistically significant and positive; however, the effects are not entirely consistent across the two volatility measures. Statistical significance is also not consistent across the volatility measures for women. The results for the coefficient of variation only indicate a statistically significant, positive effect with respect to positive household income volatility. The decomposition approach suggests that negative shocks to household income increase the probability of divorce; positive shocks have no effect on the probability of divorce for women.

Supplementary models are also estimated for two different income groups: (i) a lower-income group and (ii) a higher-income group. The effects of household income volatility on divorce differ across the two income groups. For example, neither positive 
nor negative household income volatility changes the divorce risk for lower-income women; however, increases in both raise the divorce risk for higher-income women. Negative household income volatility increases the divorce risk for men lower-income group; positive shocks do not appear to affect men's risk of divorce in the lower-income group. Both positive and negative household income volatility increase the divorce risk for men in the higher-income group.

This paper proceeds as follows. Section II provides a brief discussion of marriage and divorce models and reviews the findings with respect to the effects of earnings shocks on divorce. Section III describes the data and construction of the sample. Section IV discusses the empirical strategy along with more detailed descriptions of the household income volatility measures. Section V presents the results. Section VI concludes.

\section{BACKGROUND INFORMATION}

\section{A. The Role of Household Income Volatility in Marriage and Divorce Models}

The theory of marriage developed by Becker $(1973,1974)$ contends that individuals sort into marriage based on economic and non-economic characteristics. ${ }^{2}$ Overall, Becker's theory contends that individuals marry others with like characteristics. For example, couples with similar education levels, intelligence, social background, race, and religion are more likely to marry and to be better matches once married. Marrying on the basis of like characteristics implies that the traits are complementary, also referred to as

\footnotetext{
${ }^{2}$ Becker $(1973,1974)$ also contends that couples marry to specialize in market and household work and to achieve higher levels of marriage-specific investment such as additions to human capital, property, and children.
} 
positive assortative mating. In contrast, Becker's theory suggests that negative assortative mating occurs with respect to earnings, which implies that spousal earnings are substitutes. ${ }^{3}$ If couples sort into marriages based on earnings, household income volatility should affect divorce behavior, as the returns from marriage would change.

In their seminal article, Becker et al. (1977) posit that a decrease in the expected value of characteristics in which positive marital sorting occurs increases the risk of divorce. They also contend that unexpected events and differences in actual minus expected values of characteristics should also increase the risk of divorce. ${ }^{4}$ All of these factors, of which measures of household income volatility could proxy, affect divorce propensities by changing the returns from marriage.

The effects of household income volatility on divorce could also be tested in the context of a divorce-threat model. ${ }^{5}$ Divorce-threat models imply that the incomes received by husbands and wives shift bargaining power between spouses. That is, spouses who have higher incomes exert greater bargaining power, as they possess more control over family resources. Individuals who divorce value the outside option, which is divorce, more than the option of remaining married. ${ }^{6}$ For example, large negative shocks to the husband's income may increase the value of the outside option for the wife at the threat point; thus, divorce could occur. Alternatively, a large positive shock to the

\footnotetext{
${ }^{3}$ Earnings may be substitutable because one spouse may specialize in market work and other may specialize in home production. Becker $(1973,1974)$ contends that specialization between spouses provides additional returns to marriage.

${ }^{4}$ Their theory also predicts that increases in age at marriage, investments in marriage-specific capital, and increases in the length of marriage are expected to reduce divorce propensities. Education is expected to have an ambiguous effect on divorce.

${ }^{5}$ See Lundberg and Pollak (1996) and Bergstrom (1996) for detailed discussion of models of household behavior including divorce-threat models.

${ }^{6}$ In a number of models, the threat point is interpreted as divorce; however, in others, the threat point is a noncooperative equilibrium within marriage. See Lundberg and Pollak $(1993,1996)$ for a discussion of noncoopertative marriage models.
} 
husband's income may either increase or decrease the value of the outside option for the wife. On the one hand, it could be that positive household income shocks to the husband's income stabilize marriages through increases in the returns from marriage. However, it could also be that a positive shock to the husband's income induces the wife to file for divorce because of the benefits associated with the divorce settlement. The directional effect of positive household income volatility on divorce may also depend on the underlying property-division laws in a particular state, as women typically receive greater benefits in community property states and men typically receive greater benefits in common law states.

The model developed by Hess (2004) provides another theoretical channel to test the implications of household income volatility on divorce. As in Hess (2004), the decision to marry could provide couples with a way to hedge against income risk. Negative shocks to one spouse's income can be offset by the other spouse's income. Hence, marriage offers spouses a form of consumption insurance. If couples use marriage as a hedge against income risk, large reductions in household income could induce marital instability because of the ineffectiveness of the marriage hedge.

\section{B. Previous Empirical Findings}

In contrast to Becker's predictions, there has been little empirical support for negative assortative mating based on earnings. ${ }^{7}$ However, Zhang and Liu (2003) is an exception. They find weak evidence of negative assortative mating with respect to wage rates. Smith (1979), Becker (1981), and Nakosteen et al. (2004) find evidence of positive

\footnotetext{
${ }^{7}$ Lam (1998) develops a theoretical model that discusses potential reasons for the lack of empirical support for negative assortative mating on wages. Lam also provides a brief survey of the other findings with respect to assortative mating.
} 
assortative mating with respect to earnings and earnings residuals. ${ }^{8}$ Similarly, Chadwick and Solon (2002) find a substantial elasticity between daughters' (wives') earnings and the earnings of the family in which they were raised. The authors also find a similar elasticity between the daughter's husband's earnings and the earnings of the daughter's family, which provides more support for positive assortative mating with respect to earnings. The evidence supporting positive assortative mating based on earnings suggests that household income shocks should affect divorce propensities.

In Becker et al. (1977), unanticipated events or earnings shocks, measured as the actual earnings minus predicted earnings, tend to raise the probability of divorce for both men and women. ${ }^{9}$ Whether the measure of unexpected events is positive or negative has no bearing on the statistically significant, positive effect on divorce. Weiss and Willis (1997) use NLS data to examine the effects of unexpected changes in predicted earnings capacity on the likelihood of divorce. ${ }^{10}$ They find that an increase in predicted earnings capacity decreases the probability of divorce for men; however, the effect is positive for women.

Charles and Stephens (2004) use PSID data to examine the effect of negative earnings shocks, measured as job displacement, on divorce. They examine three types of job displacement: (i) layoffs, (ii) plant closings, and (iii) disability. They find no evidence that plant closings or disabilities translate into a greater risk of divorce. However, layoffs

\footnotetext{
${ }^{8}$ Nakosteen et al.'s (2004) results are likely to be more accurate, since the authors are able to observe individuals both before and after marriage. Most data sets do not allow the pre-marital characteristics of individuals who eventually marry to be identified.

${ }^{9}$ Becker et al. (1977) also find that difficulties in conceiving children also raise the probability of divorce. This is also used as a measure of unexpected events or surprises.

${ }^{10}$ Weiss and Willis (1997) also add to the literature by incorporating match quality into the divorce equation. The authors suggest that match quality has permanent and transitory components. If constant mean and constant covariance assumptions hold, match quality can be accounted for by including fixed effects in the divorce equation.
} 
positively affect divorce propensities. Since plant closings, disabilities, and layoffs have similar long-run earnings effects, they conclude that a spouse's non-economic suitability may play a more significant role than pecuniary matters.

The majority of these studies, with the exception of Hess (2004), examine the effect of own earnings measures on the divorce propensity. Conversely, Hess incorporates the incomes of both spouses and examines their correlation, mean difference, and relative variances. ${ }^{11}$ Using NLSY data, Hess finds that increases in relative spousal income volatility increases the probability of divorce. ${ }^{12}$ Hess also accounts for the potential endogentiy bias associated with income by using exogenous variation in the occupations of individuals. One possible limitation of Hess's analysis is that positive and negative income shocks are not identified. Hess examines relative income variances of spouses as a measure of income volatility, which makes identifying positive and negative income shocks difficult.

My approach differs from Hess's (2004) and other research on determinants of divorce propensities in four ways. First, I consider spousal incomes jointly. Second, I separately identify the effects of positive and negative household income shocks. Third, I attempt to address potential match quality issues by including individual-specific fixed effects and by controlling for marriage-duration effects. Fourth, I estimate the effects of household income volatility on divorce for lower- and higher-household income individuals.

\footnotetext{
${ }^{11}$ The results indicate that increases in the correlation of spousal incomes tend to raise the probability of divorce. Hess also finds that the mean difference of spousal incomes is not statistically significant from zero.

${ }^{12}$ Hess (2004) uses the variance of the breadwinner's income relative to the other spouse's income to construct the volatility measure.
} 


\section{DATA}

I use data from the 1979 cohort of the National Longitudinal Survey of Youth (NLSY79) to examine the effects of household income volatility on divorce. The NLSY79 is a nationally representative panel data set, which is appropriate for analyzing dynamic processes such as divorce decisions. In 1979, the survey began interviewing 12,686 respondents between the ages of 14 and 22. The original sample contained 6,283 women and an oversample of blacks, Hispanics, low-income whites, and military personnel. In 1984 and 1990, the military and the low-income white oversamples were dropped, respectively. The NLSY79 surveyed individuals annually until 1994 and then biennially thereafter. Each survey collects information on demographics along with individual labor-market and familial characteristics. The survey provides a way to analyze divorce decisions because the necessary information is available and is consistently provided in all survey years.

In each of the survey years, the NLSY79 collects information regarding respondents' marital status. Specifically, the survey identifies never married, married, separated, widowed, and divorced individuals in each year. The fact that the survey identifies the marital status of each individual in all years allows me to construct the appropriate sample with which to examine divorce behavior in response to household income volatility over time.

The key explanatory variables use a measure of family income, which contains all sources of family income and is provided in each of the survey years. To obtain a real measure of family income, the measure is deflated by the implicit price deflator for Gross Domestic Product. I discuss the ways in which the household income volatility measures 
are constructed in Section IV.

The estimation procedure uses the entire sample period. Because the survey is biennial after 1994, examining divorce decisions could present problems. It is possible for an individual to divorce twice in a two-year period. However, most divorces take considerable time to become finalized, especially if property and children are involved. It may also take a considerable time to find a new spouse. ${ }^{13}$

To construct the appropriate sample, all individuals who marry during the survey are identified. ${ }^{14}$ I exclude anyone who is married at the beginning of the survey, as information on the individual and their spouse is not available for the years that they were married before the survey began. After identifying individuals who marry over the course of the survey, I construct a marriage duration variable, which is used to construct the appropriate sample. Individuals with a missing value for the duration of marriage exit the sample. Therefore, in the years following divorce, individuals will receive a missing value for the marriage duration variable and as a result will exit the sample unless they remarry in the following years. ${ }^{15}$ The divorce outcome variable, which is a zero/one indicator variable, is formed by using the marriage duration variable. For example, an individual who marries in 1981 and divorces in 1989 would receive a zero for each year of marriage and a one for the year the individual divorces. If the individual does not remarry in 1990 or the years thereafter, the individual will no longer be in the sample

\footnotetext{
${ }^{13}$ Limiting the sample to surveys conducted annually does not change the signs and statistical significance of the household income measures. The magnitudes of the effects do change slightly; in several cases, the effects become larger.

${ }^{14}$ Some research uses measures of marital dissolution as a measure of marital instability (e.g., Becker et al. 1977; Weiss and Willis 1997), which implies that outcome variable is not only divorce but separation as well. Since individuals are legally married if they report being separated, I count separated individuals as being married.

${ }^{15}$ Individuals who remarry re-enter the sample because their marriage duration variable no longer has a missing value.
} 
because they will have missing value for the divorce outcome and the marriage-duration variable. $^{16}$

Next, I exclude all married individuals who have household income less than \$20,000 and greater than $\$ 200,000$. The household income restrictions are used because one of the household income volatility measures is sensitive to low levels of household income (see discussion of equation (1) in Section IV). It is also unlikely that negative shocks to household income for high-income households would have the same effect because the financial stress would not be as great. There are also very few observations for individuals with of household income in excess of $\$ 200,000$.

After deletions are made, the sample contains only individuals who have married at some point over the sample period and who have household income fitting the previously-mentioned criteria. Since I use two different measures of household income volatility, the number of observations and the number of individuals observed in the empirical models differ. For the first measure of household income volatility, there 608 men examined with 3,001 person-year observations and there are 646 women examined with 3,169 person-year observations. The model for the second measure of household income volatility has 1,658 person-year observations for men and 1,637 person-year observations for women. The number of men and women analyzed are 441 and 448 , respectively.

In supplemental analyses, I examine lower- and higher-income individuals separately. To conduct the supplemental analyses, I partition men and women into two household income groups: (i) the $\$ 5,000$ to $\$ 40,000$ range and (ii) the $\$ 40,000$ to $\$ 200,000$ range.

\footnotetext{
${ }^{16}$ Individuals who have been widowed or have never been married receive missing values for the divorce outcome; thus, they are not in the sample.
} 
These household income restrictions roughly divide the sample in half and provide ample observations to estimate the divorce equations for the two household income groups. With the exception of the household income restrictions, constructing the sample for the supplemental models follows the same rules as the full sample.

Using data from the NLSY79 offers a way to follow young individuals into their adulthood. At the end of the sample period, individuals would most likely have reached or would be at least approaching the peak of their earnings potential. As a result, this survey is well suited for analyzing changes in divorce behavior with respect to household income fluctuations over time, as individuals should experience periods of household income volatility throughout the sample period.

\section{ECONOMETRIC METHODOLOGY}

The goal of this paper is to identify the effect of household income volatility on the

probability of divorce. ${ }^{17}$ I use two measures of household income volatility because of the differing assumptions governing the measures and the potential endogeneity problem associated with one of the measures. I discuss estimation issues in what follows.

Measures of income uncertainty or volatility differ based on the assumptions governing the individual's expectations of future income flows (Robst et al. 1999). The first measure of household income volatility, the coefficient of variation over three year periods $(\mathrm{CV})$, measures dispersion in household income over time. Using the $C V$ as a measure of household income volatility assumes that the individual possesses little knowledge concerning future household income flows. As a result, this measure of

\footnotetext{
${ }^{17}$ The measures of volatility used here resemble the techniques used by Haurin (1991) and Robst et al. (1999).
} 
household income volatility may be inadequate. Most individuals would expect some household income growth as they gain experience and more job skills. ${ }^{18}$ Formally, the coefficient of variation is

$$
C V_{i, t}=\frac{\sigma_{i, t}^{*}}{\mu_{i, t}^{*}} .
$$

The subscripts $i$ and $t$ index individuals and time, respectively. The term $\sigma^{*}$ is the standard deviation of household income over three year periods and $\mu^{*}$ is the average of household income over three year periods. The divorce equation includes the $C V$ measure along with the log of real household income $(H I)$ to examine the relationship between household income volatility and divorce.

The specification of the divorce equation is

$$
y_{i, t}^{*}=c_{i}+\beta_{1} H I_{i, t}+\beta_{2} C V_{i, t}+\beta_{3}\left(D_{i, t} \times C V_{i, t}\right)+\beta_{4} \mathbf{X}_{i, t}+\varepsilon_{i, t} .
$$

The variables $H I$ and $C V$ are defined above. The variable $y^{*}$ is a binary variable taking on a value of one when the individual divorces and zero when married; $c$ represents an individual-specific fixed effect; $\mathbf{X}$ is a vector of control variables, which includes the individual's age, marriage duration, a squared term of their marriage duration, educational attainment, the number of children, regional indicators, and time indicators; and $\varepsilon$ is an error term. The term $(D \times C V)$ is an interaction term that captures decreases in $\mu^{*}$ over time. The variable $D$ takes on a value of one when $\mu^{*}$ at period $t$ is less than $\mu^{*}$ at period $t-1$. Therefore, interacting $D$ and $C V$ allows for the effects of negative and

\footnotetext{
${ }^{18}$ Problems also surface for the $C V$ measure when the mean value of income is close to zero. When this is the case, the $C V$ measure is very sensitive to large changes in the standard deviation of household income. As I discussed in the previous section, I address this issue by excluding individuals with household income below $\$ 20,000$. However, I relax the household income restrictions in order to examine lower-income households.
} 
positive household income shocks to be isolated. The $\beta_{i}$ are parameters to be estimated.

Attention focuses on the parameters $\beta_{2}$ and $\beta_{3}$ in equation (2), which measure the effect of positive and negative household income volatility, respectively. Summary statistics depicting the difference in the household income volatility measure used in equation (2) between individuals who divorce and those who do not divorce are shown in TABLE 1 . As TABLE 1 indicates, individuals who divorce, on average, have both higher levels of positive and negative household income volatility.

There is a potential endogeneity problem with respect to household income and, as a result, the $C V$ measure. ${ }^{19}$ The inclusion of $c$ eliminates time-invariant traits that may induce bias because of correlation between unobservables and the household income variables or the variables in $\mathbf{X}$. The estimates are consistent if unobservables are timeinvariant and there is no simultaneity bias. If unobservables are not time-invariant, then results may be biased. Adding fixed effects to the model proxies for match quality, as in Weiss and Willis (1997). ${ }^{20}$

Including $c$ does nothing to correct for the potential simultaneity bias associated with household income and divorce. Johnson and Skinner (1986) find that women begin increasing their labor supply as the probability of divorce increases. This would ultimately result in a simultaneous relationship between increases in the risk of divorce and increases in household income. As wives increase their labor supply in response to

${ }^{19}$ Ressler and Waters (2000) implement a simultaneous equation model of divorce and female earnings. Their results imply that single equation divorce models will most likely overstate the relationship between female earnings and divorce, unless the identification strategy incorporates additional exogenous information in the model.

${ }^{20}$ In some cases, one may prefer to control for a wide-range of covariates. Because of data limitations, some necessary control variables are not available. Other research has shown the importance of age at marriage, religious upbringing, cohabitation, and children from previous marriages in divorce decisions (e.g., Becker et al. 1977 and Weiss and Willis 1997). Unfortunately, some of this information is not available in the NLSY79. However, many of these variables are time-invariant. Therefore, the influence of these variables can be removed from the model by including fixed effects. 
an increase in the risk of divorce, household income would also increase. Sen (2002) finds that Johnson and Skinner's (1986) results still hold, but notes that the increase in the labor supply of women because of an increase in the risk of divorce has diminished over time.

The assumptions governing equation (1) and the potential enodgeneity problem associated with $H I$ and $C V$ in equation (2) are the reasons for including an alternative measure of household income volatility. The second measure assumes that individuals have knowledge about their future income streams, which are based on observable labormarket characteristics. Individuals know the characteristics of other individuals and the income they receive for their labor-market characteristics (Robst et al. 1999). As a result, this measure is believed to be a more realistic measure of household income volatility.

The second measure uses a first-stage regression of $H I$ on the variables in $\mathbf{X}$ and other variables expected to predict household income. ${ }^{21}$ Formally, I estimate

$$
\ln H I_{i, t}=\gamma_{0}+\gamma_{1} \mathbf{O}_{i, t}+\gamma_{2} \mathbf{L}_{i, t}+\gamma_{3} \mathbf{C}_{i, t}+\gamma_{4} \mathbf{X}_{i, t}+\xi_{i, t} .
$$

O represents the occupation indictors; $\mathbf{L}$ represents individual labor-market characteristics including job tenure, a squared term of educational attainment, and an indicator for participation in a labor union; $\mathbf{C}$ represents county-level variables including the unemployment rate, the percent of the population that is (are) black, Hispanic, medical doctors, high-school educated, college educated, employed in the manufacturing sector, employed in the retail sector, and employed in the public sector; $\mathbf{X}$ is defined above; and $\xi$ is an error term. The $\gamma_{i}$ are parameters to be estimated.

\footnotetext{
${ }^{21}$ Equation (3) takes a log-linear functional form because the specification yields a better model fit (Heckman and Polachek 1974). There is also no need to control for individual-unobserved heterogeneity in equation (3) because the specification of the divorce equation will eliminate all fixed effects; thus, nothing is lost by estimating the first-stage regression by ordinary least squares (OLS).
} 
The occupation indicators in $\mathbf{O}$ potentially provide a source of exogenous variation with which to identify the effect of household income and household income volatility on divorce. An individual's occupation should not be correlated with the divorce variable; however, household income and the occupations of individuals should be correlated. Hess (2004) also uses occupation indicators as instruments to identify the effect of relative spousal income volatility on the probability of divorce. He also shows that the occupation indicators are jointly excludable in the divorce equations.

The second household income volatility measure uses the predicted values of $H I$ and the predicted value of $\xi$ from equation (3) to specify the different components of household income. The predicted value of $\xi$ represents the uncertain portion of household income $(H I)$. Interest does not focus on the parameter estimates of equation (3). There is a need, however, to control for as many factors as possible that are expected to influence household income. Omission of a key variable could lead to the uncertain portion $(\xi)$ of household income not being attributable to uncertainty, rather an omitted variable. ${ }^{22}$ After estimating equation (3), the mean of the residual series over three year periods $\left(\mu^{\xi}\right)$ and the standard deviation of the residual series over three year periods $\left(\sigma^{\xi}\right)$ enter the divorce equation along with the permanent income component $\left(\mu^{I}\right) .^{23}$ The terms $\mu^{\xi}$ and $\sigma^{\xi}$ represent the transitory and volatility components of household income, respectively. For the second specification, the divorce equation is

\footnotetext{
${ }^{22}$ Although there are most likely omitted variables in equation (3), I have included as many factors as possible. However, the NLSY79 is limited in that it does not provide a great deal of information on spouse's educational attainment, job tenure, and experience, all of which should affect household income. However, it could be that the omitted factors are exogenous to the individual. If in fact the omitted factors are exogenous to the individual, the unobserved portion of household income should represent the uncertain portion of household income.

${ }^{23}$ The permanent income component is the average predicted value of household income over three year periods.
} 


$$
\begin{aligned}
y_{i, t}^{*}= & c_{i}+\theta_{1} \mu_{i, t}^{I}+\theta_{2} \mu_{i, t}^{\xi}+\theta_{3} \sigma_{i, t}^{\xi} \\
& +\theta_{4}\left(D_{i, t} \times \mu_{i, t}^{\xi}\right)+\theta_{5}\left(D_{i, t} \times \sigma_{i, t}^{\xi}\right) \\
& +\theta_{6} \mathbf{X}_{i, t}+v_{i, t} .
\end{aligned}
$$

The terms $y^{*}, c, \mu^{I}, \mu^{\xi}, \sigma^{\xi}, D$, and $\mathbf{X}$ are defined above. The variable $v$ is an error term. The $\theta_{i}$ are parameters to be estimated. The estimation procedure focuses on the parameters $\theta_{3}$ and $\theta_{5}$, which measure the effect of positive and negative household income volatility, respectively. Summary statistics depicting the differences in the household income volatility measures used in equation (4) between individuals who divorce and those who do not divorce are shown in TABLE 2. The statistics shown in TABLE 2 suggest that individuals who experience greater levels of household income volatility, regardless of whether the volatility measure is positive or negative, are more likely to divorce. The statistics shown in TABLE 2 are consistent with the comparison made in TABLE 1.

Equations (2) and (4) are estimated by ordinary least squares (OLS). Estimating a binary outcome by OLS does present a problem; the predicted outcome is not constrained to be between zero and 100 percent. $^{24}$ It should be noted that if one examines the predicted divorce probabilities by evaluating the minimum and maximum summary statistics of the household income volatility measures, the predicted outcomes are not below zero percent and do not exceed 100 percent.

\footnotetext{
${ }^{24}$ Logit and probit specifications do constrain predicted outcomes. However, when fixed effects enter the logit specification, individuals who have time-invariant outcomes are dropped. The result is a large reduction in the number of observations, which leads to insignificant results. The incidental parameters problem has the potential to surface when fixed effects enter the probit specification. The advantage of estimating the outcome by OLS with fixed effects is that time-invariant outcomes are not dropped from the model and no incidental problem exists.
} 


\section{RESULTS}

The estimates shown in TABLES 3 and 4 provide the key contribution of this paper, which show the results from equations (2) and (4) for the entire sample. The estimates for the other explanatory variables from equations (2) and (4) are shown in TABLES A1 and A2, respectively. Recall that equation (4) uses equation (3) to construct the household income measures. The occupation indicators included in equation (3) provide a potential source of exogenous variation with which to identify the effects of household income volatility on divorce. TABLE A3 shows the estimates for the occupation indicators in equation (3), which suggest that the occupation indicators have significant predictive power in the first-stage models. ${ }^{25}$ TABLE A4 shows the estimates for the occupation indicators when included in equation (4). The results suggest that the occupation indicators are unrelated to the divorce decision. Since the occupation indicators are correlated with household income and uncorrelated with divorce, they provide a source of exogenous variation with which to identify the effects of household income volatility on divorce. TABLES 5 and 6 show the results for the supplementary models from equation (2). TABLES 7 and 8 present the estimates for the supplementary models from equation (4). The supplementary models include estimates for lower- and higher- income individuals.

I estimate all models by OLS with and without fixed effects. The models with fixed effects are the preferred estimates because of the importance of many time-invariant

\footnotetext{
${ }^{25}$ Note that the number of observations used in the first-stage regression differ from the number of observations used to estimate the divorce equations. The numbers of observations differ because I estimate equation (3) for all household income groups. For the divorce equations, I partition individuals into different household income groups: (i) the $\$ 20,000$ to $\$ 200,000$ household income range, (ii) the $\$ 5,000$ to $\$ 40,000$ household income range, and (iii) the $\$ 40,000$ to $\$ 200,000$ household income range.
} 
factors that have been shown in the literature (e.g., religious upbringing, previous marriages, the presence of children from previous marriages, etc.). ${ }^{26}$ These factors, as well as other unobservables, could be correlated with the household income measures, which could bias estimates. I present the OLS estimates along with the fixed effects estimates in the TABLES because it is illuminating to observe the changes in the estimates when fixed effects enter the models. In many cases, the coefficients and the statistical significance of the estimates change dramatically once fixed effects enter the models, which may suggest that time-invariant unobservables that are removed by including fixed effects are likely to be correlated with the household income measures.

The results shown in TABLE 3 indicate that increases in the level of household income have a substantial stabilizing effect on marriages for both men and women, which is consistent with previous findings (e.g., Becker et al. 1977; Hoffman and Duncan 1995; Burgess et al. 2003). Positive household income volatility is statistically significant and positive for men. For women, positive household income volatility is statistically significant and positive in both the OLS and fixed effects specifications; however, the magnitude of the effect increases slightly when fixed effects enter the model. The effect of negative household income volatility for men and women is not statistically different from zero when fixed effects enter the model; however, the effects are statistically significant in the OLS specifications.

TABLE 4 shows the results from equation (4). Recall that equation (4) uses exogenous variation in the occupations of individuals to identify the effect of the household income measures on divorce. The estimates from equation (4) suggest that increases in the

\footnotetext{
${ }^{26}$ For example, see Weiss and Willis (1997) and Charles and Stephens (2004). They highlight the importance of accounting for match quality when examining divorce behavior in response to earnings shocks.
} 
permanent income component stabilize marriages for men and women; however, the effect becomes statistically insignificant once fixed effects enter the model for women. There is a statistically significant, positive increase in the risk of divorce due to increases in positive and negative household income volatility for men. However, women only experience a statistically significant, positive increase in the risk of divorce from increases in negative household income volatility.

TABLES 5 and 6 present the results from equation (2) for lower- and higher-income individuals, respectively. The stabilizing effect associated with increases in the level of household income is consistent with the findings in TABLE 3, regardless of whether the individual has a low or high level of household income. For the lower-income group, men face a decrease in the divorce risk in response to positive household income volatility and an increase in the divorce risk in response to negative household income volatility. Neither positive nor negative household income volatility has an effect on the divorce propensity for lower-income women. The results for the higher-income group differ from the lower-income group. Increases in negative household income volatility have a positive effect on the divorce risk for men; however, there is no evidence that negative shocks alter the divorce risk for women. Positive household income shocks do not affect the divorce risk for men; however, they have a positive effect on the divorce risk for women.

TABLES 7 and 8 provide the estimates from equation (4) for lower- and higher-income groups, respectively. TABLES 7 and 8 also show the joint-exclusion statistic for the occupation indicators when they enter the divorce equations for men and women in the two household income groups. The exclusion statistics indicate the occupation indicators 
are unrelated to the divorce decision. Therefore, they also provide a source of exogenous information for the lower- and higher-household income groups. The results suggest that permanent household income is not statistically different from zero for women in both household income groups. However, the permanent income component has a stabilizing effect on divorce for men in the lower-income group. There is no evidence that the permanent income component affects the divorce propensity for higher-income men. For the lower-income group, negative household income volatility increases the divorce propensity for both men and women. Positive household income volatility decreases the divorce risk for women, but has no effect on the divorce behavior of men. The results for the higher-income group differ from the lower-income group, which was also the case for the estimates from equation (2). Both men and women face an increase in the divorce propensity in response to increases in positive and negative household income volatility.

Because of the potential simultaneity bias associated with household income and divorce in equation (2), it is difficult to make any conclusions from the estimates. As can be seen by comparing the estimates, the estimates of equation (2) differ-sometimes dramatically—from the estimates generated by the two-stage procedure (i.e. equations (3) and (4)). The use of the exogenous information in the first-stage model appears to be the point of departure with the estimates. Thus, the results from equation (4) are the preferred estimates for the full sample and the sample used for the supplementary models.

The main results for men (i.e. TABLE 4) largely confirm Becker et al.'s (1977) theoretical predictions and their empirical findings. My findings for women are not completely consistent with their theory or empirical results. I find that positive household income volatility has no effect on the divorce risk and negative household 
income volatility increases the divorce risk. The former is not consistent with Becker et al.'s (1977) theory and empirical findings, which suggests that unexpected events or earnings shocks raise the divorce risk regardless of whether they are positive or negative. A potential explanation is that positive household income volatility could stem from an increase in husband's earnings, which may imply that the value of the outside option for the wife is less when her husband's income increases. However, it could raise the value of the outside option for men. These competing effects may imply that the directional impact on the incentives of spouses to divorce-attributable to positive household income volatility - counter each other. Therefore, positive household income shocks may have no effect on divorce propensities. The differing results found for the low- and high-income groups suggest that the two groups respond differently to fluctuations in household income. However, both groups seem to be affected similarly by negative household income volatility, which raises the risk of divorce for both groups regardless of gender. The positive impact of negative household income volatility on divorce may suggest that reductions in the returns from marriage precipitate a rise in divorce. Women in the lower-income group face a reduction in the divorce risk because of positive household income volatility. The reduction in the divorce risk for women could be due to the additional returns associated with the positive household income shock. The results for the higher-income group confirm Becker et al.’s (1977) predictions and findings.

Since it is not possible to determine which spouse filed for divorce, it is difficult to determine precisely how household income volatility affects the divorce decisions of spouses. That is, husbands and wives could be affected differently by shocks to household income. For example, it could be that men receive more outside marriage 
offers when they experience positive income shocks. However, if the positive shock is derived from the wife, then it could be that the positive income shock generates a selfreliance effect for women. Both the former and the latter may translate into a higher risk of divorce.

The underlying property-division laws could also affect the divorce decision in response to positive household income shocks. A positive shock to household income could induce either spouse to file for divorce. On the one hand, an increase in husband's income may induce the wife to file for divorce because of the property-division laws in place. On the other hand, an increase in wives' income could induce the husband to file for divorce because alimony payments and other transfers may be less if the wife experiences a positive shock to her income.

\section{CONCLUSIONS}

This paper estimates the effect of both positive and negative household income volatility on divorce for men and women using two measures of household income volatility constructed from the NLSY79. There are two major issues that must be addressed when examining the effects of earnings shocks on divorce behavior: $(i)$ exogenizing measures of earnings or income in the divorce equations and (ii) controlling for the quality of marriage match. I address these issues by using exogenous variation in the occupations of individuals, which is similar to the approach by Hess (2004), and by including an individual-specific fixed effect and controlling for marriage-duration effects.

The results largely confirm the majority of previous findings, which indicate the importance of earnings and earnings shocks in divorce decisions. Analyzing the full 
sample yields results that suggest that men face an increased risk of divorce from increases in household income volatility, regardless of the volatility measure and whether the shock stems from positive or negative household income shocks. The preferred estimates indicate that women face an increased risk of divorce when there is increases negative household income volatility. No effect is found with respect to positive household income volatility for women. The latter differs from the theory and findings of Becker et al. (1977).

The results found in this paper suggest that household income measures have substantial effects on divorce behavior. The main results are largely consistent with the findings by Becker et al. (1977), Weiss and Willis (1997), and Hess (2004). My findings are not consistent with the interpretation offered by Charles and Stephens (2004), who contend that nonpecuniary factors may be better predictors of divorce behavior than pecuniary factors. 


\section{REFERENCES}

Becker, Gary S. 1973. “A Theory of Marriage: Part I.” Journal of Political Economy, 81(4): 813-846.

. 1974. “A Theory of Marriage: Part II.” Journal of Political Economy, 82(2): S11-

S26.

. 1981. A Treatise on the Family. Cambridge: Harvard University Press.

, Elisabeth M. Landes, and Robert T. Michael. 1977. "An Economic Analysis of

Marital Instability.” Journal of Political Economy, 85(6): 1141-1188.

Bergstrom, Theodore. 1996. "Economics in a Family Way." Journal of Economic Literature, 34(4): 1903-1934.

Blundell, Richard and Luigi Pistaferri. 2003. "Income Volatility and Household Consumption: The Impact of Food Assistance Programs.” Journal of Human Resources, 38(sup.): 1032-1051.

Burgess, Simon, Carol Propper, and Arnstein Aassve. 2003. "The Role of Income in Marriage and Divorce Transitions Among Young Americans.” Journal of Population Economics, 16(3): 455-475.

Chadwick, Laura and Gary Solon. 2002. "Intergenerational Income Mobility Among Daughters.” American Economic Review, 92(1): 335-344.

Charles, Kerwin. 1999. "Sickness in the Family: Health Shocks and Spousal Labor Supply.” Unpublished Manuscript. University of Michigan. and Melvin Stephens. 2004. “Job Displacement, Disability, and Divorce.” Journal of Labor Economics, 22(2): 489-522.

Cullen, Julie and Jonathan Gruber. 2000. "Does Unemployment Insurance Crowd Out 
Spousal Labor Supply?” Journal of Labor Economics, 18(3): 546-572.

Haurin, Donald R. 1991. “Income Variability, Home Ownership, and Housing Demand.” Journal of Housing Economics, 1(1): 60-74

Heckman, James J. and Soloman Polachek. 1974. "Empirical Evidence on the Functional Form of the Earnings-Schooling Relationship.” Journal of the American Statistical Association, 69(346): 350-354.

Hess, Gregory D. 2004. “Marriage and Consumption Insurance: What's Love Got to Do with It? Journal of Political Economy, 112(2): 290-318.

Hoffman, Saul and Greg Duncan. 1995. "The Effect of Incomes, Wages, and AFDC Benefits on Marital Disruption.” Journal of Human Resources, 30(1): 19-41.

Johnson, William and Jonathan Skinner. 1986. "Labor Supply and Marital Separation.” American Economic Review, 76(3): 455-469.

Lam, David. 1988. "Marriage Markets and Assortative Mating with Household Public Goods: Theoretical Results and Empirical Implications.” Journal of Human Resources, 23(4): 462-487.

Lundberg, Shelly and Robert Pollak. 1993. "Separate Spheres Bargaining and the Marriage Market.” Journal of Political Economy, 101(6): 988-1010. . 1996. "Bargaining and Distribution in Marriage." Journal of Economic Perspectives, 10(4): 139-158.

Nakosteen, Robert, Olle Westerlund, and Michael Zimmer. 2004. "Marital Matching and Earnings: Evidence from the Unmarried Population in Sweden.” Journal of Human Resources, 39(4): 1033-1044.

Ressler, Rand W. and Melissa S. Waters. 2000. "Female Earnings and the Divorce Rate: 
A Simultaneous Equations Model.” Applied Economics, 32(14): 1889-1898.

Robst, John, Richard Deitz, and Kim McGoldrick. 1999. "Income Variability, Uncertainty, and Housing Tenure Choice.” Regional Science and Urban Economics, 29(2): 219-229.

Sen, Bisakha. 2000. "How Important is Anticipation of Divorce in Married Women’s Labor Supply Decisions? An Intercohort Comparison Using NLS Data.” Economic Letters, 67(2): 209-216.

Smith, James. 1979. "The Distribution of Family Earnings." Journal of Political Economy, 87(5): S163-S192.

Stephens, Melvin. 2001. "The Long-run Consumption Effects of Earnings Shocks." Review of Economics and Statistics, 83(1): 28-36. . 2003. "Job Loss Expectations, Realizations, and Household Consumption Behavior.” Working Paper 9508, National Bureau of Economic Research, Cambridge, MA.

Weiss, Yoram and Robert Willis. 1997. "Match Quality, New Information, and Marital Dissolution.” Journal of Labor Economics, 15(1): S293-S329.

Zhang, Junsen and Pak-Wai Liu. 2003. “Testing Becker’s Prediction on Assortative Mating on Spouses’ Wages.” Journal of Human Resources, 38(1): 99-110. 


\begin{tabular}{|c|c|c|c|c|}
\hline \multicolumn{5}{|c|}{$\begin{array}{c}\text { TABLE } 1 \\
\text { COMPARISON OF HOUSEHOLD INCOME } \\
\text { VOLATILITY MEASURES FROM EQUATION } 2\end{array}$} \\
\hline \multirow{2}{*}{ Variable } & \multicolumn{2}{|c|}{ Not Divorced } & \multicolumn{2}{|c|}{ Divorced } \\
\hline & Mean & Std. Dev. & Mean & Std. Dev. \\
\hline \multicolumn{5}{|l|}{ Men: } \\
\hline Positive Household & 0.2371 & 0.2637 & 0.2517 & 0.2369 \\
\hline Income Volatility $(\mathrm{CV})$ & & & & \\
\hline $\begin{array}{l}\text { Negative Household } \\
\text { Income Volatility }(D * C V)\end{array}$ & 0.0520 & 0.1314 & 0.1088 & 0.1921 \\
\hline \multicolumn{5}{|l|}{ Women: } \\
\hline $\begin{array}{l}\text { Positive Household } \\
\text { Income Volatility }(\mathrm{CV})\end{array}$ & 0.2441 & 0.2619 & 0.2929 & 0.2725 \\
\hline $\begin{array}{l}\text { Negative Household } \\
\text { Income Volatility }(D * C V)\end{array}$ & 0.0544 & 0.1496 & 0.1482 & 0.2238 \\
\hline \multicolumn{5}{|c|}{$\begin{array}{l}\text { Notes: The numbers of observations for men are 3,001 and there are 3,169 for women. The } \\
\text { statistics above are computed by restricting the sample to those who do not divorce and those } \\
\text { who do divorce over the sample period. These statistics provide a source of comparison between } \\
\text { the levels of household income volatility that individuals who do not divorce and those who do } \\
\text { divorce experience. }\end{array}$} \\
\hline
\end{tabular}




\section{TABLE 2}

COMPARISON OF HOUSEHOLD INCOME VOLATILITY MEASURES FROM EQUATION 4

\begin{tabular}{|c|c|c|c|c|}
\hline \multirow[b]{2}{*}{ Variable } & \multicolumn{2}{|c|}{ Not Divorced } & \multicolumn{2}{|c|}{ Divorced } \\
\hline & Mean & Std. Dev. & Mean & Std. Dev. \\
\hline $\begin{array}{l}\text { Men: } \\
\text { Positive Volatility } \\
\text { Comnonent }\left(\sigma^{\xi}\right)\end{array}$ & 0.2159 & 0.2140 & 0.3406 & 0.3691 \\
\hline $\begin{array}{l}\text { Negative Volatility } \\
\text { Component }\left(D^{*} \sigma^{\xi}\right)\end{array}$ & 0.0552 & 0.1335 & 0.1313 & 0.2919 \\
\hline $\begin{array}{l}\text { Women: } \\
\text { Positive Volatility } \\
\text { Component }\left(\sigma^{\xi}\right)\end{array}$ & 0.2536 & 0.2550 & 0.3237 & 0.2708 \\
\hline $\begin{array}{l}\text { Negative Volatility } \\
\text { Component }\left(D^{*} \sigma^{\xi}\right)\end{array}$ & 0.0685 & 0.1737 & 0.1646 & 0.2283 \\
\hline
\end{tabular}

Notes: The numbers of observations for men are 3,001 and there are 3,169 for women. The statistics above are computed by restricting the sample to those who do not divorce and those who do divorce over the sample period. These statistics provide a source of comparison between the levels of household income volatility that individuals who do not divorce and those who do divorce experience. 


\section{TABLE 3}

\section{RESULTS FROM EQUATION 2 FOR THE FULL SAMPLE}

\begin{tabular}{|c|c|c|c|c|}
\hline \multirow[b]{2}{*}{ Variable } & \multicolumn{2}{|c|}{ Men } & \multicolumn{2}{|c|}{ Women } \\
\hline & OLS & $\begin{array}{l}\text { OLS with } \\
\text { Fixed effects }\end{array}$ & OLS & $\begin{array}{l}\text { OLS with } \\
\text { Fixed Effects }\end{array}$ \\
\hline $\begin{array}{l}\text { Log of Real } \\
\text { Household Income } \\
(H I)\end{array}$ & $\begin{array}{l}-0.0881^{* * * *} \\
(0.013)\end{array}$ & $\begin{array}{l}-0.1256^{* * *} \\
(0.019)\end{array}$ & $\begin{array}{l}-0.0977 * * * \\
(0.012)\end{array}$ & $\begin{array}{l}-0.1696 * * * \\
(0.016)\end{array}$ \\
\hline $\begin{array}{l}\text { Positive Household } \\
\text { Income Volatility } \\
(\mathrm{CV})\end{array}$ & $\begin{array}{l}0.0669 * * * \\
(0.021)\end{array}$ & $\begin{array}{l}0.1196 * * * \\
(0.026)\end{array}$ & $\begin{array}{l}0.0902 * * * \\
(0.021)\end{array}$ & $\begin{array}{l}0.1024 * * * \\
(0.023)\end{array}$ \\
\hline $\begin{array}{l}\text { Negative Household } \\
\text { Income Volatility } \\
(D * C V)\end{array}$ & $\begin{array}{l}0.1133 * * * \\
(0.044)\end{array}$ & $\begin{array}{l}0.0268 \\
(0.043)\end{array}$ & $\begin{array}{l}0.0939 * * \\
(0.041)\end{array}$ & $\begin{array}{l}-0.0170 \\
(0.036)\end{array}$ \\
\hline R-squared & 0.2604 & 0.2389 & 0.2446 & 0.2094 \\
\hline $\begin{array}{l}\text { Number of } \\
\text { Observations }\end{array}$ & 3,001 & 3,001 & 3,169 & 3,169 \\
\hline
\end{tabular}

Notes: standard errors are in parentheses. * indicates statistical significance at the ten percent level, ** indicates statistical significance at the five percent level, and $* * *$ indicates statistical significance at the one percent level. All models are estimated using OLS. Each model contains demographic and regional covariates. The models also include time indicators. 
TABLE 4

RESULTS FROM EQUATION 4 FOR THE FULL SAMPLE

Men

\begin{tabular}{|c|c|c|c|c|}
\hline \multirow[b]{2}{*}{ Variable } & \multicolumn{2}{|c|}{ Men } & \multicolumn{2}{|c|}{ Women } \\
\hline & OLS & $\begin{array}{l}\text { OLS with } \\
\text { Fixed Effects }\end{array}$ & OLS & $\begin{array}{l}\text { OLS with } \\
\text { Fixed Effects }\end{array}$ \\
\hline $\begin{array}{l}\text { Permanent } \\
\text { Component } \\
\left(\mu^{I}\right)\end{array}$ & $\begin{array}{l}-0.1021^{* * *} \\
(0.029)\end{array}$ & $\begin{array}{l}-0.1744^{* * *} \\
(0.049)\end{array}$ & $\begin{array}{l}-0.0498 * \\
(0.029)\end{array}$ & $\begin{array}{l}-0.0763 \\
(0.054)\end{array}$ \\
\hline $\begin{array}{l}\text { Positive Transitory } \\
\text { Component } \\
\left(\mu^{\xi}\right)\end{array}$ & $\begin{array}{l}-0.0126 \\
(0.024)\end{array}$ & $\begin{array}{l}-0.0658 * * \\
(0.033)\end{array}$ & $\begin{array}{l}-0.0928 * * * \\
(0.021)\end{array}$ & $\begin{array}{l}-0.1352 * * * \\
(0.029)\end{array}$ \\
\hline $\begin{array}{l}\text { Positive Volatility } \\
\text { Component } \\
\left(\sigma^{\xi}\right)\end{array}$ & $\begin{array}{l}0.1096 * * * \\
(0.042)\end{array}$ & $\begin{array}{l}0.1156 * * * \\
(0.038)\end{array}$ & $\begin{array}{l}0.0365 \\
(0.037)\end{array}$ & $\begin{array}{l}-0.0054 \\
(0.037)\end{array}$ \\
\hline $\begin{array}{l}\text { Negative Transitory } \\
\text { Component } \\
\left(D * \mu^{\xi}\right)\end{array}$ & $\begin{array}{l}-0.0854 * * \\
(0.043)\end{array}$ & $\begin{array}{l}-0.1054 * * \\
(0.041)\end{array}$ & $\begin{array}{l}0.0461 \\
(0.049)\end{array}$ & $\begin{array}{l}0.0222 \\
(0.039)\end{array}$ \\
\hline $\begin{array}{l}\text { Negative Volatility } \\
\text { Component } \\
\left(D * \sigma^{\xi}\right)\end{array}$ & $\begin{array}{l}0.1372 * * \\
(0.062)\end{array}$ & $\begin{array}{l}0.1662 * * * \\
(0.052)\end{array}$ & $\begin{array}{l}0.1109 * * \\
(0.057)\end{array}$ & $\begin{array}{l}0.0974 * * \\
(0.046)\end{array}$ \\
\hline R-squared & 0.1830 & 0.0875 & 0.1437 & 0.0646 \\
\hline $\begin{array}{l}\text { Number of } \\
\text { Observations }\end{array}$ & 1,658 & 1,658 & 1,637 & 1,637 \\
\hline
\end{tabular}




\section{TABLE 5}

RESULTS FROM EQUATION 2

$(\$ 5,000 \leq$ HOUSEHOLD INCOME $<\$ 40,000)$

\begin{tabular}{|c|c|c|c|c|}
\hline \multirow[b]{2}{*}{ Variable } & \multicolumn{2}{|c|}{ Men } & \multicolumn{2}{|c|}{ Women } \\
\hline & OLS & $\begin{array}{l}\text { OLS with } \\
\text { Fixed Effects }\end{array}$ & OLS & $\begin{array}{l}\text { OLS with } \\
\text { Fixed Effects }\end{array}$ \\
\hline $\begin{array}{l}\text { Log of Real } \\
\text { Household Income } \\
(H I)\end{array}$ & $\begin{array}{l}-0.0542 * * * \\
(0.016)\end{array}$ & $\begin{array}{l}-0.0653^{* * *} \\
(0.024)\end{array}$ & $\begin{array}{l}-0.0834^{* * *} \\
(0.015)\end{array}$ & $\begin{array}{l}-0.1092 * * * \\
(0.021)\end{array}$ \\
\hline $\begin{array}{l}\text { Positive Household } \\
\text { Income Volatility } \\
(\mathrm{CV})\end{array}$ & $\begin{array}{l}-0.0316 \\
(0.027)\end{array}$ & $\begin{array}{l}-0.0463^{* *} \\
(0.040)\end{array}$ & $\begin{array}{l}-0.0046 \\
(0.029)\end{array}$ & $\begin{array}{l}-0.0372 \\
(0.036)\end{array}$ \\
\hline $\begin{array}{l}\text { Negative Household } \\
\text { Income Volatility } \\
\left(D^{*} C V\right)\end{array}$ & $\begin{array}{l}0.0799 * * \\
(0.040)\end{array}$ & $\begin{array}{l}0.0839 * \\
(0.050)\end{array}$ & $\begin{array}{l}0.0681 * \\
(0.039)\end{array}$ & $\begin{array}{l}-0.0447 \\
(0.044)\end{array}$ \\
\hline R-squared & 0.2973 & 0.2146 & 0.3214 & 0.1053 \\
\hline $\begin{array}{l}\text { Number of } \\
\text { Observations }\end{array}$ & 1,980 & 1,980 & 2,511 & 2,511 \\
\hline
\end{tabular}

Notes: standard errors are in parentheses. * indicates statistical significance at the ten percent level, ** indicates statistical significance at the five percent level, and *** indicates statistical significance at the one percent level. All models are estimated using OLS. Each model contains demographic and regional covariates. The models also include time indicators. 


\section{TABLE 6}

RESULTS FROM EQUATION 2

$(\mathbf{\$ 4 0 , 0 0 0} \leq$ HOUSEHOLD INCOME $\leq \mathbf{\$ 2 0 0 , 0 0 0 )}$

\begin{tabular}{|c|c|c|c|c|}
\hline \multirow[b]{2}{*}{ Variable } & \multicolumn{2}{|c|}{ Men } & \multicolumn{2}{|c|}{ Women } \\
\hline & OLS & $\begin{array}{l}\text { OLS with } \\
\text { Fixed Effects }\end{array}$ & OLS & $\begin{array}{l}\text { OLS with } \\
\text { Fixed Effects }\end{array}$ \\
\hline $\begin{array}{l}\text { Log of Real Household } \\
\text { Income } \\
(H I)\end{array}$ & $\begin{array}{l}-0.0735^{* * *} \\
(0.022)\end{array}$ & $\begin{array}{l}-0.1233^{* * * *} \\
(0.024)\end{array}$ & $\begin{array}{l}-0.0578^{* * *} \\
(0.019)\end{array}$ & $\begin{array}{l}-0.1468^{* * * *} \\
(0.025)\end{array}$ \\
\hline $\begin{array}{l}\text { Positive Household } \\
\text { Income Volatility } \\
(\mathrm{CV})\end{array}$ & $\begin{array}{l}0.1011^{* * *} \\
(0.029)\end{array}$ & $\begin{array}{l}0.1293 \\
(0.033)\end{array}$ & $\begin{array}{l}0.0948 * * * \\
(0.029)\end{array}$ & $\begin{array}{l}0.0707 * * \\
(0.028)\end{array}$ \\
\hline $\begin{array}{l}\text { Negative Household } \\
\text { Income Volatility } \\
(D * C V)\end{array}$ & $\begin{array}{l}0.1048^{*} \\
(0.062)\end{array}$ & $\begin{array}{l}0.0428^{*} \\
(0.058)\end{array}$ & $\begin{array}{l}0.0993^{*} \\
(0.058)\end{array}$ & $\begin{array}{l}0.0634 \\
(0.043)\end{array}$ \\
\hline R-squared & 0.2427 & 0.2561 & 0.2065 & 0.2200 \\
\hline $\begin{array}{l}\text { Number of } \\
\text { Observations }\end{array}$ & 1,720 & 1,720 & 1,744 & 1,744 \\
\hline
\end{tabular}

Notes: standard errors are in parentheses. * indicates statistical significance at the ten percent level, ** indicates statistical significance at the five percent level, and *** indicates statistical significance at the one percent level. All models are estimated using OLS. Each model contains demographic and regional covariates. The models also include time indicators. 
TABLE 7

RESULTS FROM EQUATION 4

$(\$ 5,000 \leq$ HOUSEHOLD INCOME $<\$ \mathbf{4 0 , 0 0 0})$

\begin{tabular}{|c|c|c|c|c|}
\hline \multirow[b]{2}{*}{ Variable } & \multicolumn{2}{|c|}{ Men } & \multicolumn{2}{|c|}{ Women } \\
\hline & OLS & $\begin{array}{l}\text { OLS with } \\
\text { Fixed Effects }\end{array}$ & OLS & $\begin{array}{l}\text { OLS with } \\
\text { Fixed Effects }\end{array}$ \\
\hline $\begin{array}{l}\text { Permanent } \\
\text { Component } \\
\left(\mu^{I}\right)\end{array}$ & $\begin{array}{l}-0.0650 \\
(0.045)\end{array}$ & $\begin{array}{l}-0.2574 * * * \\
(0.096)\end{array}$ & $\begin{array}{l}0.0597 \\
(0.048)\end{array}$ & $\begin{array}{l}0.0042 \\
(0.098)\end{array}$ \\
\hline $\begin{array}{l}\text { Positive Transitory } \\
\text { Component } \\
\left(\mu^{\xi}\right)\end{array}$ & $\begin{array}{l}0.0129 \\
(0.033)\end{array}$ & $\begin{array}{l}-0.1222^{* *} \\
(0.059)\end{array}$ & $\begin{array}{l}-0.0511 \\
(0.040)\end{array}$ & $\begin{array}{l}-0.2041^{* * *} \\
(0.065)\end{array}$ \\
\hline $\begin{array}{l}\text { Positive Volatility } \\
\text { Component } \\
\left(\sigma^{\xi}\right)\end{array}$ & $\begin{array}{l}0.0938 * \\
(0.051)\end{array}$ & $\begin{array}{l}0.0354 \\
(0.072)\end{array}$ & $\begin{array}{l}0.0848 \\
(0.054)\end{array}$ & $\begin{array}{l}-0.1370^{*} \\
(0.078)\end{array}$ \\
\hline $\begin{array}{l}\text { Negative Transitory } \\
\text { Component } \\
\left(D^{*} \mu^{\xi}\right)\end{array}$ & $\begin{array}{l}-0.0308 \\
(0.054)\end{array}$ & $\begin{array}{l}-0.0570 \\
(0.066)\end{array}$ & $\begin{array}{l}-0.0536 \\
(0.067)\end{array}$ & $\begin{array}{l}0.0015 \\
(0.073)\end{array}$ \\
\hline $\begin{array}{l}\text { Negative Volatility } \\
\text { Component } \\
\left(D^{*} \sigma^{\xi}\right)\end{array}$ & $\begin{array}{l}0.1832 * * \\
(0.077)\end{array}$ & $\begin{array}{l}0.1655^{*} \\
(0.092)\end{array}$ & $\begin{array}{l}0.0127 \\
(0.064)\end{array}$ & $\begin{array}{l}0.1305^{*} \\
(0.078)\end{array}$ \\
\hline R-squared & 0.3072 & 0.0717 & 0.3325 & 0.0563 \\
\hline $\begin{array}{l}\text { Number of } \\
\text { Observations }\end{array}$ & 952 & 952 & 970 & 970 \\
\hline Exclusion Statistic: & & & & \\
\hline Occupation Indicators & $\begin{array}{l}1.24 \\
{[0.272]}\end{array}$ & $\begin{array}{l}1.58 \\
{[0.110]}\end{array}$ & $\begin{array}{l}0.56 \\
{[0.834]}\end{array}$ & $\begin{array}{l}0.30 \\
{[0.974]}\end{array}$ \\
\hline
\end{tabular}




\section{TABLE 8}

RESULTS FROM EQUATION 4

$(\mathbf{\$ 4 0 , 0 0 0} \leq$ HOUSEHOLD INCOME $\leq \mathbf{\$ 2 0 0 , 0 0 0})$

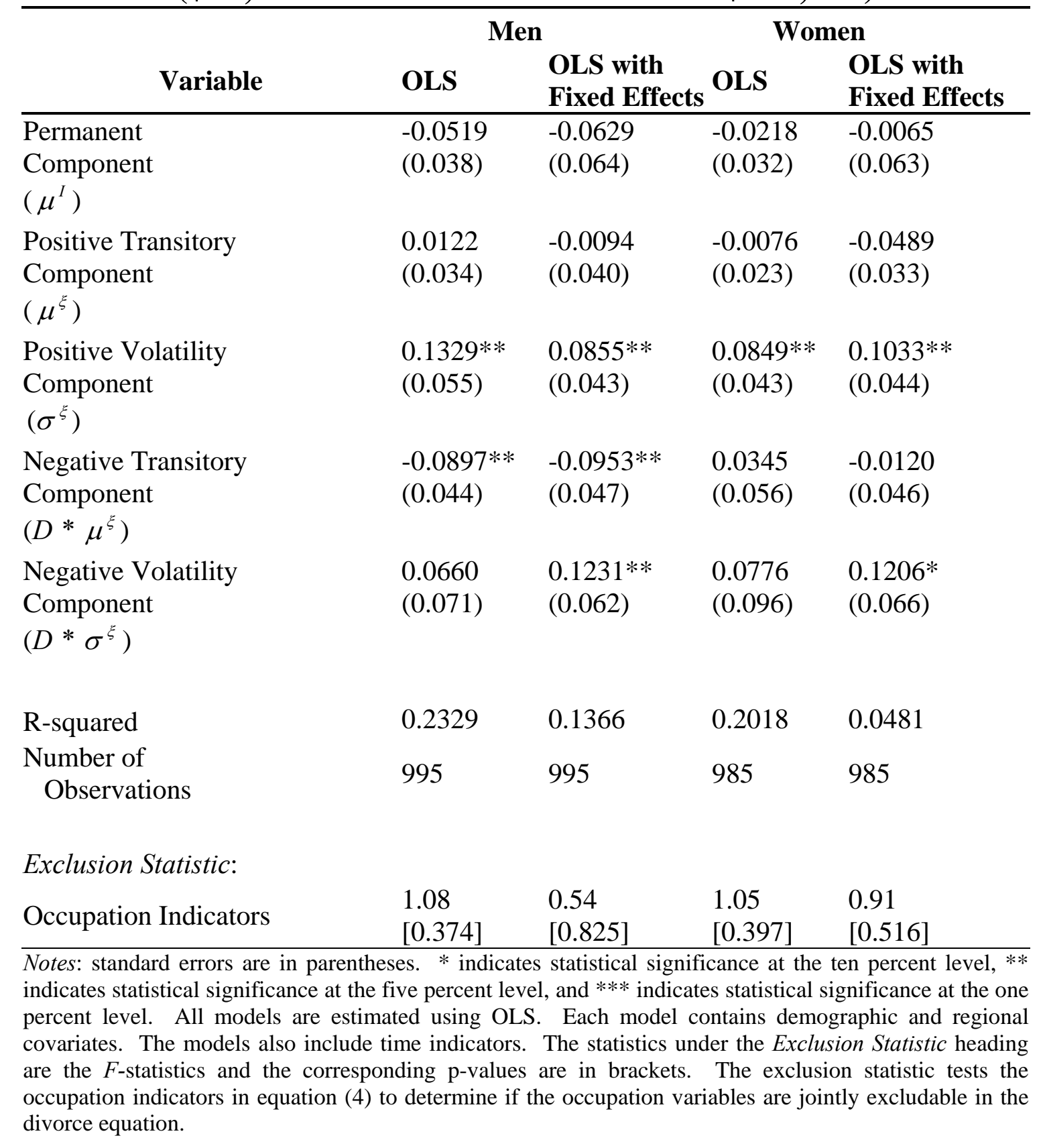


APPENDIX

- 35 - 
TABLE A1

\begin{tabular}{|c|c|c|c|c|}
\hline & 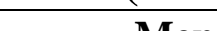 & & & \\
\hline & Men & & Womei & \\
\hline Variable & OLS & $\begin{array}{l}\text { OLS with } \\
\text { Fixed Effects }\end{array}$ & OLS & $\begin{array}{l}\text { OLS with } \\
\text { Fixed Effects }\end{array}$ \\
\hline Marriage Duration & $\begin{array}{l}0.0261^{* * *} \\
(0.005)\end{array}$ & $\begin{array}{l}0.0584^{* * *} \\
(0.006)\end{array}$ & $\begin{array}{l}0.0251^{* * *} \\
(0.005)\end{array}$ & $\begin{array}{l}0.0465^{* * *} \\
(0.006)\end{array}$ \\
\hline $\begin{array}{l}\text { Marriage Duration } \\
\text { Squared }\end{array}$ & $\begin{array}{l}-0.0009 * * \\
(0.000)\end{array}$ & $\begin{array}{l}-0.0019^{* * *} \\
(0.000)\end{array}$ & $\begin{array}{l}-0.0013^{* * *} \\
(0.000))\end{array}$ & $\begin{array}{l}-0.0017^{* * *} \\
(0.000)\end{array}$ \\
\hline Education & $\begin{array}{l}0.0027 \\
(0.002)\end{array}$ & $\begin{array}{l}-0.0259 \\
(0.014)\end{array}$ & $\begin{array}{l}0.0094^{* * * *} \\
(0.003)\end{array}$ & $\begin{array}{l}0.0340^{* * *} \\
(0.011)\end{array}$ \\
\hline Number of Children & $\begin{array}{l}-0.0691 * * * \\
(0.004)\end{array}$ & $\begin{array}{l}-0.0978^{* * *} \\
(0.007)\end{array}$ & $\begin{array}{l}-0.0211^{* * *} \\
(0.005)\end{array}$ & $\begin{array}{l}0.0454^{* * *} \\
(0.009)\end{array}$ \\
\hline Age & $\begin{array}{l}0.0093^{* * *} \\
(0.003)\end{array}$ & $\begin{array}{l}0.0108 \\
(0.018)\end{array}$ & $\begin{array}{l}0.0068^{* * *} \\
(0.002)\end{array}$ & $\begin{array}{l}0.0301 * \\
(0.017)\end{array}$ \\
\hline Northeast & $\begin{array}{l}-0.0289^{*} \\
(0.015)\end{array}$ & $\begin{array}{l}0.0125 \\
(0.052)\end{array}$ & $\begin{array}{l}-0.0167 \\
(0.015)\end{array}$ & $\begin{array}{l}-0.0356 \\
(0.044)\end{array}$ \\
\hline South & $\begin{array}{l}-0.0016 \\
(0.013)\end{array}$ & $\begin{array}{l}-0.0543 \\
(0.036)\end{array}$ & $\begin{array}{l}-0.0248^{* *} \\
(0.011)\end{array}$ & $\begin{array}{l}-0.0538 \\
(0.037)\end{array}$ \\
\hline West & $\begin{array}{l}-0.0056 \\
(0.014)\end{array}$ & $\begin{array}{l}-0.0410 \\
(0.050)\end{array}$ & $\begin{array}{l}-0.0182 \\
(0.013)\end{array}$ & $\begin{array}{l}0.0103 \\
(0.044)\end{array}$ \\
\hline Urban & $\begin{array}{l}0.0201 * \\
(0.012)\end{array}$ & $\begin{array}{l}0.0651^{* * *} \\
(0.019)\end{array}$ & $\begin{array}{l}-0.0037 \\
(0.011)\end{array}$ & $\begin{array}{l}-0.0355^{*} \\
(0.020)\end{array}$ \\
\hline $\begin{array}{l}\text { Number of } \\
\text { Observations }\end{array}$ & 3,001 & 3,001 & 3,169 & 3,169 \\
\hline
\end{tabular}

Notes: standard errors are in parentheses. * indicates statistical significance at the ten percent level, ** indicates statistical significance at the five percent level, and $* * *$ indicates statistical significance at the one percent level. The models also include time indicators. 


\begin{tabular}{|c|c|c|c|c|}
\hline \multicolumn{5}{|c|}{$\begin{array}{l}\text { TABLE A2 } \\
\text { ESTIMATES FOR EXPLANATORY VARIABLES OF EQUATION } 4 \\
\text { (FULL SAMPLE) }\end{array}$} \\
\hline \multirow[b]{2}{*}{ Variable } & \multicolumn{2}{|l|}{ Men } & \multicolumn{2}{|c|}{ Women } \\
\hline & OLS & $\begin{array}{l}\text { OLS with } \\
\text { Fixed Effects }\end{array}$ & OLS & $\begin{array}{l}\text { OLS with Fixed } \\
\text { Effects }\end{array}$ \\
\hline Marriage Duration & $\begin{array}{l}0.0101 \\
(0.008)\end{array}$ & $\begin{array}{l}0.0510 * * * \\
(0.009)\end{array}$ & $\begin{array}{l}0.0303^{* * *} \\
(0.007)\end{array}$ & $\begin{array}{l}0.0682 * * * \\
(0.009)\end{array}$ \\
\hline $\begin{array}{l}\text { Marriage Duration } \\
\text { Squared }\end{array}$ & $\begin{array}{l}0.0003 \\
(0.001)\end{array}$ & $\begin{array}{l}-0.0010^{*} \\
(0.000)\end{array}$ & $\begin{array}{l}-0.0017 * * * \\
(0.000)\end{array}$ & $\begin{array}{l}-0.0025^{* * * *} \\
(0.000)\end{array}$ \\
\hline Education & $\begin{array}{l}0.0030 \\
(0.004)\end{array}$ & $\begin{array}{l}-0.0682 * * * \\
(0.026)\end{array}$ & $\begin{array}{l}0.0102^{* *} \\
(.005)\end{array}$ & $\begin{array}{l}0.0486 * * * \\
(0.019)\end{array}$ \\
\hline Number of Children & $\begin{array}{l}-0.0690 * * * \\
(0.007)\end{array}$ & $\begin{array}{l}-0.1109 * * * \\
(0.010)\end{array}$ & $\begin{array}{l}-0.0109 \\
(0.007)\end{array}$ & $\begin{array}{l}-0.0592 * * * \\
(0.015)\end{array}$ \\
\hline Age & $\begin{array}{l}0.0108 * * * \\
(0.004)\end{array}$ & $\begin{array}{l}0.0275 \\
(0.025)\end{array}$ & $\begin{array}{l}0.0081^{* *} \\
(0.004)\end{array}$ & $\begin{array}{l}0.0437^{*} \\
(0.025)\end{array}$ \\
\hline Northeast & $\begin{array}{l}-0.0377 * * \\
(0.019)\end{array}$ & $\begin{array}{l}-0.0260 \\
(0.085)\end{array}$ & $\begin{array}{l}-0.0114 \\
(0.023)\end{array}$ & $\begin{array}{l}-0.0530 \\
(0.112)\end{array}$ \\
\hline South & $\begin{array}{l}0.0006 \\
(0.017)\end{array}$ & $\begin{array}{l}0.0070 \\
(0.077)\end{array}$ & $\begin{array}{l}-0.0138 \\
(0.016)\end{array}$ & $\begin{array}{l}-0.1674 * * \\
(0.074)\end{array}$ \\
\hline West & $\begin{array}{l}-0.0033 \\
(0.020)\end{array}$ & $\begin{array}{l}0.0993 \\
(0.126)\end{array}$ & $\begin{array}{l}-0.0268 \\
(0.019)\end{array}$ & $\begin{array}{l}-0.0720 \\
(0.076)\end{array}$ \\
\hline Urban & $\begin{array}{l}0.0451^{* *} \\
(0.018)\end{array}$ & $\begin{array}{l}0.0952 * * * \\
(0.036)\end{array}$ & $\begin{array}{l}0.0031 \\
(0.019)\end{array}$ & $\begin{array}{l}-0.0643^{*} \\
(0.037)\end{array}$ \\
\hline $\begin{array}{l}\text { Number of } \\
\text { Observations }\end{array}$ & 1,658 & 1,658 & 1,637 & 1,637 \\
\hline
\end{tabular}

Notes: standard errors are in parentheses. * indicates statistical significance at the ten percent level, ** indicates statistical significance at the five percent level, and $* * *$ indicates statistical significance at the one percent level. The models also include time indicators. 


\section{TABLE A3}

\section{ESTIMATES FOR THE OCCUPATION INDICATORS}

FROM THE FIRST-STAGE MODEL (EQUATION 3)

\begin{tabular}{|c|c|c|c|c|}
\hline Variable & \multicolumn{2}{|c|}{ Men } & \multicolumn{2}{|c|}{ Women } \\
\hline Professional & $0.3720 * * *$ & $(0.073)$ & 0.0796 & $(0.083)$ \\
\hline Manufacturing & $0.3287 * * *$ & $(0.074)$ & 0.0985 & $(0.083)$ \\
\hline Sales & $0.3566 * * *$ & $(0.082)$ & 0.0214 & $(0.087)$ \\
\hline Clerical & $0.2116 * * *$ & $(0.076)$ & 0.0100 & $(0.079)$ \\
\hline Craftsman & $0.2038 * * *$ & $(0.070)$ & 0.0417 & $(0.093)$ \\
\hline Operations & $0.1573 * *$ & $(0.071)$ & -0.1186 & $(0.083)$ \\
\hline Laborer & 0.0620 & $(0.074)$ & $-0.1647^{*}$ & $(0.100)$ \\
\hline Service & 0.0651 & $(0.074)$ & $-0.1793 * *$ & $(0.080)$ \\
\hline Private & -0.2894 & $(0.268)$ & $-0.1804 * *$ & $(0.104)$ \\
\hline Joint-Exclusion Test & \multicolumn{2}{|c|}{$\begin{array}{l}12.26 * * * \\
{[0.000]}\end{array}$} & \multicolumn{2}{|c|}{$\begin{array}{l}11.45^{* * *} \\
{[0.000]}\end{array}$} \\
\hline $\begin{array}{l}\text { Number of } \\
\text { Observations }\end{array}$ & \multicolumn{2}{|c|}{3,810} & \multicolumn{2}{|c|}{4,072} \\
\hline
\end{tabular}

Notes: Equation (3) is estimated by OLS and also includes demographic characteristics, labor-market characteristics, county-level covariates, and time indicators as control variables. Standard errors are in parentheses. * indicates statistical significance at the ten percent level, ** indicates statistical significance at the five percent level, and *** indicates statistical significance at the one percent level. 


\section{TABLE A4}

ESTIMATES FOR OCCUPATION INDICATORS WHEN ADDED TO EQUATION 4

(FULL SAMPLE)

\begin{tabular}{|c|c|c|c|c|}
\hline \multirow[b]{2}{*}{ Variable } & \multicolumn{2}{|c|}{ Men } & \multicolumn{2}{|c|}{ Women } \\
\hline & OLS & $\begin{array}{l}\text { OLS with } \\
\text { Fixed Effects }\end{array}$ & OLS & $\begin{array}{l}\text { OLS with } \\
\text { Fixed Effects }\end{array}$ \\
\hline \multirow[t]{2}{*}{ Professional } & -0.0039 & -0.0522 & 0.0338 & 0.1614 \\
\hline & $(0.093)$ & $(0.100)$ & $(0.119)$ & $(0.099)$ \\
\hline \multirow[t]{2}{*}{ Manufacturing } & -0.0078 & -0.0831 & 0.0598 & 0.1539 \\
\hline & $(0.093)$ & $(0.100)$ & $(0.119)$ & $(0.099)$ \\
\hline \multirow[t]{2}{*}{ Sales } & -0.0134 & -0.1068 & -0.0020 & 0.1052 \\
\hline & $(0.094)$ & $(0.105)$ & (0.119) & $(0.103)$ \\
\hline \multirow[t]{2}{*}{ Clerical } & -0.0028 & -0.0623 & 0.0208 & 0.1582 \\
\hline & $(0.094)$ & $(0.103)$ & $(0.118)$ & $(0.097)$ \\
\hline \multirow[t]{2}{*}{ Craftsman } & 0.0216 & -0.0194 & 0.0595 & 0.1771 \\
\hline & $(0.092)$ & $(0.097)$ & $(0.130)$ & $(0.097)$ \\
\hline \multirow[t]{2}{*}{ Operations } & -0.0010 & -0.0287 & -0.0114 & 0.0469 \\
\hline & $(0.092)$ & $(0.097)$ & $(0.118)$ & $(0.098)$ \\
\hline \multirow[t]{2}{*}{ Laborer } & 0.0250 & -0.0738 & -0.0258 & 0.0568 \\
\hline & $(0.094)$ & (0.099) & $(0.128)$ & $(0.111)$ \\
\hline \multirow[t]{2}{*}{ Service } & 0.0037 & -0.1071 & 0.0059 & 0.1332 \\
\hline & $(0.094)$ & $(0.103)$ & $(0.118)$ & $(0.101)$ \\
\hline \multirow[t]{2}{*}{ Private } & -0.0058 & -0.3099 & -0.0190 & 0.0783 \\
\hline & $(0.098)$ & $(0.286)$ & (0.119) & $(0.133)$ \\
\hline \multirow[t]{2}{*}{ Joint-Exclusion Test } & 0.42 & 1.19 & 1.42 & 1.47 \\
\hline & {$[0.966]$} & [0.297] & [0.173] & [0.154] \\
\hline $\begin{array}{l}\text { Number of } \\
\text { Observations }\end{array}$ & 1,658 & 1,658 & 1,637 & 1,637 \\
\hline
\end{tabular}

Notes: All models include demographic characteristics, labor-market characteristics, county-level characteristics, and time indictors as control variables. Standard errors are in parentheses. Note that all of the occupation indicators are not statistically significant from zero in all divorce equations. Likewise, joint-exclusion tests indicate that the occupation indicators are excludable in the divorce equations. 